\title{
La constitución de la identidad marginada en Señas de identidad de Juan Goytisolo
}

Palbras clave: novela de posguerra, identidad, otredad, marginación

\section{Introducción}

«Hay ciertos viajes de los que solo a la vuelta se comienza a saber» (María Zambrano, 1995: 13)

La novela marcada por el compromiso moral y político es la característica común de los escritores de los mediados del siglo XX (Rodríguez Cacho, 2009: 423). De ahí proviene la tendencia neorrealista, caracterizada por la voluntad testimonial y humanitaria, junto con la novela social que muestra una denuncia más directa (Rodríguez Cacho, 2009: 424). En ambos casos descubrimos las huellas de la Guerra civil en la literatura española, convirtiéndola en una escritura más íntima alternada por la desgracia humana (Abradelo Usera, 2005: 52). Por lo tanto, la necesidad íntima de los novelistas de la posguerra fue reconstruir y recuperar una realidad desgarrada durante los años de la guerra, proveyéndose de escritura con talante autobiográfico, donde encontramos al autor de la novela Señas de identidad del año 1966', Juan Goytisolo (De Asís Garrote, 2005: 47). Como representante de la generación «los niños de la guerra», Goytisolo tiende a la reconstrucción del pasado nacional, reviviéndolo a través de personajes que sentían perdida su identidad en relación con la Patria propagadora del franquismo (Rodríguez Cacho, 2009: 454). Esta tendencia

1 La novela forma parte de Trilogía de Álvaro Mendiola, seguida por las novelas Don Julián (1970) (anteriormente titulada Reivindicación del Conde don Julián) y la novela titulada Juan sin Tierra (1977), en las que el autor crea versiones del protagonista Álvaro Mendiola, desarraigándole paulatinamente hasta la última novela (Sanz Villanueva, 2012: 23). 
fundamenta la novela Señas de identidad y el protagonista Álvaro Mendiola, que en su mundo narrativo recrea el pasado de su antigua patria, reuniendo las señas que forman parte del su ser.

Al llevar a su protagonista Álvaro a encontrar señas diseminadas entre la vida cotidiana de su pueblo, de sus amigos y su familia, Goytisolo entra en el terreno de la novelística social. La temática de las novelas sociales está vinculada por la simple narración de los sucesos de la vida cotidiana que forman una crónica del acontecer nacional en todos sus sectores: los oficios y ocupaciones, las migraciones, el ambiente rural o el mundo burgués (Pope, 1999: 457-458). El uso de los mencionados temas proviene de la necesidad de reconstruir la identidad nacional, enmascarada por los mecanismos de la industrialización, el turismo y la dictadura. Así, los rasgos de la novela social cumplen su función como un recurso narrativo de Goytisolo, requisito para la formación de una identidad verdadera que se expande debajo de los números ilustres de la estadística franquista. La novela que tenemos ante nosotros busca una indagación en la realidad nacional, y según Javier Cercas: «esta indagación se lleva a cabo a través de dos procedimientos: cuestionamiento da la tradición española [...]» (en Barrero Pérez y Cercas, 1999: 357). Esta tendencia también coincide con los rasgos representativos de la literatura de los años sesenta, durante los cuales predominó «la convicción de servir a una causa, la de la libertad y la justicia» (Sanz Villanueva, Sobejano, 1999: 526).

El camino que seguía Goytisolo, junto con otros representantes de este periodo, fue el del testimonialismo (Sanz Villanueva, Sobejano, 1999: 528), vinculado por la necesidad de representar la vida misma en la forma más transparente. Recordemos en este punto que el protagonista de Señas de identidad es estudiante de dirección cinematográfica, que toma la iniciativa de rodar un documental de carácter social, convirtiéndose así en una especie de historiador social. Esta tendencia objetivista tuvo como resultado un cambio formal vertiginoso que llevó a Goytisolo hacia una narrativa de corte experimental, llevada a cabo ya en Señas de identidad. Bajo la influencia de los escritores hispanoamericanos, Goytisolo abandona el lenguaje tradicional, entendiéndolo como un elemento de la depauperación general de España (Sanz Villanueva, Sobejano, 1999: 529). Justamente esta variación de lenguaje facilitó la construcción de una realidad nacional entrecortada y caleidoscópica, y de un protagonista en búsqueda continua de su identidad diseminada. Por lo tanto, la lucha lingüística de Goytisolo se comprende como la crítica del momento histórico-social de la España franquista: «Para criticar la realidad del país era 
preciso empezar por la crítica de su lenguaje» (Goytisolo, 1977: 165). Precisamente este es el paso que forma el camino literario de Goytisolo.

Según Goytisolo, la labor desmitificadora es parte inseparable de su vocación literaria, y debería triunfar sobre la mitificación de la historiografía oficial (Soldevila Durante, 2001: 256). El mismo título de la novela ya lo representa, mostrándonos una identidad distanciada de las estructuras centrípetas y míticas, obligada a un rumbo desorientado. Esta posición sirve de un punto ideal para cumplir con el deber desmitificador y contribuye a la revelación de la maquinaria controladora ético-social, que consigue producir y controlar el conocimiento que tenemos de nuestro Yo y de nuestra identidad. Sin embargo, al distanciarse uno llega a ser un exiliado, lo que es un denominador común para textos de Juan Goytisolo (Goytisolo, 1977: 289). Esta posición permite la deformación y luego reformación de los conocimientos nacionales, políticos, sexuales y otros productos de imagología vencedora (Osborne, Wintle, 2006: 16), lo cual conducirá a Goytisolo hacia una reivindicación de lo marginado.

Podríamos decir que la identidad exiliada es también el constructo imagológico de una ideología predominante, pero un constructo que hizo el camino por etapas opuestas. Esto es lo que conduce a un exiliado a buscarse a sí mismo sin definirse. En palabras de Edward Said (2000: 179), el exiliado tiene una necesidad urgente de completar su identidad a partir de los trozos y discontinuidad de su vida en exilio, y es esta la razón por la cual el exilio es una condición que lleva a la negación y continua aniquilación de la identidad, esto es, de las identidades que tuvo. Conforme a esto Goytisolo teje su narrativa proveyéndose de diferentes discursos, historias personales e imágenes ideológicas que entrecruzan formando «una enciclopédica variedad de discursos represores» (Ugarte, 1999: 489), que giran en torno a la identidad exiliada. Al presentar al exiliado como distanciado de la patria, Goytisolo crea un perfil que todos los exiliados comparten: el del ser marginado. ¿ن cómo está constituida su identidad? Al comprender las señas que el exiliado Álvaro Mendiola sigue como los semas constituyentes de una palabra, nos acercaremos a la respuesta esperada.

\section{La constitución vía imágenes genealógicas}

Tratando la cuestión de identidad, Paul Ricoeur, destaca la diferencia entre identidad como la mismidad, e identidad como la ipseidad² (2004: 123). La

2 Según la noción de Paul Ricoeur (Riker en la escritura serbia), la ipseidad (ipse), puede ser igualada al carácter personal e invariable, que se manifiesta a través de la mismidad (ídem) (Riker 2004: 122-132). 
identidad comprendida entre estos dos conceptos se refleja en una identidad continua (sin interrupción alguna) y perdurable. Así la busca por la identidad personal implica una búsqueda de lo invariable en todas las relaciones, es decir, el punto de cruce entre la mismidad e ipseidad. A continuación, Ricoeur (2004: 128) pone de relieve que la identidad de una persona está constituida por el proceso de identificación con las normas, los ideales, los valores y los modelos en los cuales uno puede percibirse a sí mismo. Podemos vislumbrar que con esta motivación Goytisolo reintroduce a su protagonista exiliado en el entorno de las señas que marcaron su primera identidad -su casa familiar.

Al regresar al país que Álvaro Mediola había abandonado muchos años antes, su identidad se confronta a los portavoces de la ideología franquista, que resaltan la contrariedad de su identidad del hijo pródigo de familia burguesa, y por otra parte del hijo blasfemo y desviado, caracterizado como «enlutado sabihondo y mendaz rabia salserillo» (Goytisolo, 2005: 13), creando desde el principio de la novela la noción de la vida marginada y desdoblada. Álvaro Mendiola se encuentra disgregado, por lo cual trata de encontrarse a sí mismo a través de los primeros moldes que le dieron la forma. Conforme a esto toma el álbum familiar y resucita las imágenes de su niñez. Releyendo y reintegrando los objetos del pasado, Álvaro llega a «desenterrar uno a uno de la polvorienta memoria de los singulares y heteróclitos elementos que componían el decorado mítico de (su) niñez [...] las vetustas y marchitas habitaciones» (Goytisolo, 2005: 16).

El álbum familiar, la pérdida clave de su niñez y juventud, resulta ser un recurso narrativo de Goytisolo para presentar a su lector el mundo narrativo que conforma una familia burguesa, monárquica y poseedora de los Mendiola. El proceso de investigación del álbum familiar y de las memorias infantiles está representado paralelamente con los pensamientos de Álvaro en el presente narrativo (el año 1963), con la experiencia del exiliado y de un hijo desviado del camino que su familia le había determinado. El mundo que pertenece a las historias del álbum está constituido por los recuerdos, y precisamente de ese mundo Álvaro había huido primordialmente sintiéndose diferente de la programación de sus familiares. Por lo tanto, el contraste entre las imágenes y los pensamientos de Álvaro resulta ser la causa de la separación de la primera identidad - la separación del niño Álvaro. Los recuerdos infantiles que forman la gran parte del capítulo I de la novela son las señas que formaron su primera identidad, que está en una clase de enemistad con el Álvaro correspondiente al presente narrativo. El niño Álvaro pertenece al discurso de 
centro de la estructura social, y el adulto ha llegado a pertenecer al margen de esta estructura.

Los momentos decisivos para la separación de la primera identidad de Álvaro Mendiola serían el desengaño religioso y la visita a su abuela en un monasterio en el capítulo I. Siendo educado de un modo puramente cristiano, bajo la vigilancia de la señorita Lourdes, el niño Álvaro sentía una influencia profunda de la fe y de las historias de la vida de los niños mártires. La idea del sacrificio empezó a ocupar la imaginación del niño, que buscaba su identidad a través de la unión con lo divino. El día señalado, pequeño Álvaro vestido de blanco y con la reliquia de la Santa Cruz colgada del cuello, salió por las calles barcelonesas desertadas por los partidarios ideológicos de su familia, y con las iglesias y conventos ardiendo. Se fue con la señorita Lourdes para encontrar su lugar de unión con Dios, invocando los nombres de Jesús y María y siguiendo el camino de su primera identificación imagológica. Sin embargo, el camino se interrumpe con la aparición de un hombre malo, barbudo y mal vestido (los epítetos relacionados con los miembros de la $\mathrm{FAI}^{3}$ ), y la identificación con los mártires soñada desapareció sin milagros. Es entonces cuando de la formación de la identidad de Álvaro desaparecieron las imágenes religiosas, que se convirtieron en un universo frío y estéril, de arrepentimiento y pecado, de plegaria y pupitre. Así comenzó la desviación del árbol genealógico de los Mendiola.

El siguiente fragmento de la memoria infantil está relacionado con el alejamiento de la familia y todos los moldes que imponía, y tiene la fecha de octubre de 1939, que es revivida a través del retrato de la abuela materna del pequeño Álvaro. El primer conocimiento de Álvaro del empobrecimiento ético-social del mundo burgués al que pertenecía su familia, fue durante la visita a su abuela que sufría de anamnesis. Al ver que su abuela no le reconocía, esquivando la mirada y volviéndole la espalda, Álvaro sintió como si su pasado y él mismo no hubiesen existido nunca, y dio el segundo paso hacia el desarraigo genealógico. Es entonces cuando todos los enlaces entre su familia y él empezaron a deshacerse, y «Álvaro había aprendido a conocer los límites de su condición y [...] sabía que todo, incluido el mismo, no era definitivo y perdurable como confiadamente creyera hasta entonces» (Goytisolo, 2005: 57).

Estos momentos de la vida infantil de Álvaro se resolvieron en su posterior distanciamiento del mundo burgués, que apoyaba al franquismo, y de un mundo marcado por la tradición religiosa y colonial, que Goytisolo seguirá incitando para combatir los mitos operantes en la sociedad española (Sanz

3 Federación Ibérica Anárquica. 
Villanueva, 1977:85). Puesto que «la labor mitoclasta ha de operar dinamitando el mito desde su interior» (Sánchez Vidal, 1980: 30), Goytisolo eligió la posición para su objetivo: la de un niño nacido en la cuna de los representantes del mito de la España eterna.

Álvaro seguiría encontrando las señas de su identidad a través de las ataduras genealógicas también al nivel del pasado reciente: durante el rodaje de su documental en la provincia de Yeste, y durante la visita a Ginebra con Dolores. Un específico estrato de la memoria que importunaba a Álvaro consistía en las imágenes de violencia del poderío que empiezan con el discurso oficial de la Guardia Civil: «Por favor, su documentación» (Goytisolo, 2005: 155). En fragmentos paralelos, pero en diferentes cronotopos, este discurso relaciona el destino de Álvaro y de su tío Lucas, matado por los hombres de FAI, y de su primo Sergio, recogido en un camión de la FAI y muerto a los dieciséis años. El mismo Álvaro sufre la represión introducida por la famosa sentencia de control y poderío de Autoridad superior, que ha guardado su cámara y sus películas de la vida provincial. Así Álvaro encontró su identidad vinculada también por los destinos trágicos de sus parientes, revelando una historia que se repite cambiando las formas.

El pasado recuperado a través de las imágenes que entornan a Álvaro Mendiola en su casa familiar sirve de instrumento de balance de su existencia. Además, entendidas como las señas de una identidad de la que había huido, ayudan en establecer su identidad que vino después, y que perduraría en su posición marginada en el mundo de la España mítica. Esta nueva identidad de Álvaro mantiene una enemistad dialéctica con la primera, que empezó y desapareció con la niñez, durante el desengaño que trajo la guerra (Anderson, 1974: 12).

\section{La constitución vía Otredad}

La identidad es producto de la maquinaria ideológica que moldea a las personas y sus identidades a través de imágenes, y por lo tanto está en continua transición (Osborne, Wintle, 2006: 18). Así Álvaro Mendiola empezó a cambiar las imágenes moldeadoras de su nueva identidad, buscándose a sí mismo en lo despreciado por el mundo que él mismo había empezado a rechazar. Aquí se entiende lo despreciado como una especie de Otro que forma parte de la misma sociedad, estando posicionado en el margen de los estratos sociales. Según palabras de Levinas (en Levinas, Peperzak, 2005: 19) es precisamente el Otro el que debe ser reconocido para disminuir un monismo ontológico 
para que la sociedad funcione a nivel de reciprocidad entre las identidades de diferentes sustratos y clases. A continuación, Levinas (2005: 22) destaca que el Otro viene únicamente si su apariencia deconstruye y destruye los horizontes de un monismo egocéntrico, un universo en que todos los fenómenos están arreglados según las reglas de este universo unificador, que observa el Otro en su naturaleza enigmática. Este pensamiento filosófico lo podemos comprender como el material del que Goytisolo había empezado el entretejido de la identidad exiliada de Álvaro.

Las palabras de Levinas casi pueden servir como descripción del encuentro del niño Álvaro y Jerónimo, jornalero de treinta y dos años que pertenecía al grupo revolucionario de los maquis. Primero lo veía extraño, distante y como un enemigo que interrumpió en su vida: «En aquella época la vida transcurría [...] tranquila y falaz como una sucesión de cromos de colores proyectados en una linterna mágica, secretamente minada en su base por el soterrado enemigo» (Goytisolo, 2005: 46). Esta imagen del Otro empezó a intrigarle, haciéndole espiar a Jerónimo, para luego trabar una amistad con él. Así es como Álvaro pasó el límite entre los lados opuestos, y se acercó al mundo marginado desde su clase burgués. Este acercamiento es el fruto de una admiración del niño por el sacrificio que un revolucionario brindaba a la libertad -la linterna vital de la identidad exiliada formada muchos años después de este encuentro crucial. Llegada la noticia sobre su desaparición, el mundo interior de Álvaro es pintado por un sentimiento de frío hacia el mundo que lo rodeaba desde el nacimiento, y un dolor profundo mezclado con la vergüenza por la muerte de un luchador para libertad. Esta es la nueva moralidad despertada por la identificación con el primer Otro introducido en el mundo del niño Álvaro.

Al alejar su protagonista de la niñez, Goytisolo lo traslada paulatinamente a otro mundo -el mundo universitario y emancipador. En un grupo de amigos reunidos en su casa familiar, quienes habían interrumpido la revivificación de los recuerdos silenciosos de la infancia, Álvaro salta al cronotopo de su adolescencia. Entonces empiezan a rodar las imágenes de la vida estudiantil, las vidas de sus amigos Ricardo, Enrique, Artigas y Antonio, que le rodean en el proceso del restablecimiento del pasado. El episodio que hizo a Álvaro acercarse al mundo marginal, está relacionado con su amistad con Sergio, rico y desinteresado, que le llevó a Álvaro en su MG descapotable a recorrer escenas de la vida de Barcelona desconocidas para Álvaro hasta entonces. Una ciudad extraña y sucia que Álvaro observaba por la ventana del automóvil de Sergio fue su descubrimiento más importante, por lo desconocido y lejano. Así es como 
Goytisolo lleva a su protagonista focalizado(r) a encontrarse entre la gente de la Otredad barcelonesa y burguesa, entre las putas, carteristas, maricones, marginados en los barrios desconocidos, dirigidos al margen por la represión social. Al pasar la frontera del mundo noble, Álvaro entró en el mundo de los bajos fondos. La inclinación de Goytisolo hacia Foucault se vislumbra aquí, puesto que la construcción de la identidad se ve alterada por la diferencia entre un mundo normal y otro marcado como patológico y enfermo (CornejoParriego, 1998:180). Conforme con esta tendencia, Álvaro empieza a sentirse:

[...] sustraído de pronto al ozono leve y estimulante de los barrios residenciales, tenías la impresión de zambullirte en un mundo distinto, profundo y más denso, sintiendo que el oxígeno se enrarecía en tus pulmones, timorato e incierto como animal doméstico arrebatado bruscamente a su elemento natural cotidiano. (Goytisolo, 2005: 79)

Estas imágenes ahora producen un desengaño social en Álvaro Mendiola, que observa a su casta como una madrépora parasitaria, alejándose un paso más de ella, y acercándose más a los marginales. Además, esta Corte de Milagros con sus vicios y defectos sirve para cumplir con la desmitificación de la España tradicional a través de la exaltación de los marginados y desposeídos.

Pasados los años y el tiempo turbulento de la Guerra Civil, las identidades marginadas atraviesan los límites de España, trasladándose al café de madame Berger en París -son los emigrantes españoles durante y después de la guerra. A pesar de que Álvaro Mendiola formaba parte de sus paisanos emigrados, siendo emigrante él también, no podemos prescindir de la mirada que Álvaro dirige a su pueblo de sujetos dolicocéfalos. Álvaro les mira desde una perspectiva distanciada, como si fuera un investigador de esa raza fugitiva y dejada al olvido, pintando el cuadro emigrante de estratos históricamente nivelados, según los años de las crisis y revoluciones. Álvaro seguía en su posición marginada, cada vez más intensificada por sentirse diferente de sus compatriotas marginados, experimentando así las últimas raíces que le ligaban a su patria.

No obstante, las vidas de los emigrados y sus historias dolorosas, tenían una influencia profunda en el cometido que había fundamentado una invariabilidad en su identidad propiamente marginada. Miremos a las biografías de los emigrados, que Álvaro copiaba durante las preparaciones de rodaje de su documental inacabado y tomado por la Guardia Civil. Las imágenes creadas al releer esas historias que «se erguían [...] como una grave e imperecedera 
acusación» (Goytisolo, 2005: 387) son descritas metafóricamente como un «lento aprendizaje en el dolor, la vergüenza y la astucia, la injusticia y la humillación» (Goytisolo, 2005: 388). Los encarcelados, torturados, dejados a la muerte del hambre, a las bajas condiciones de la vida y a compasión de la minoría, alejados de casi toda clase de humanidad, plantaron unánimemente en Álvaro la necesidad de rodar un documental social que rescataría toda una historia clandestina y no escrita por la historiografía oficial del Poder, y que desenvuelve directamente el deseo de Goytisolo del comprender el pasado y el presente de España (Sanz Villanueva, 1977: 28).

En estas partes de la narración el autor relaciona la identidad colectiva nacional de la posguerra y la identidad individual del Álvaro exiliado, revelando las imágenes y biografías de los emigrantes como una fuente de introspección de Álvaro. A fin de cuentas, « ¿que eres?: un desterrado voluntario que duerme (doce horas diarias) come [...], bebe (litro o litro medio de tinto...), va al cine [...]» (Goytisolo, 2005: 389). De esta manera Álvaro permanece en esta continua transición que no le deja formar la imagen de su mosaico identitario. No obstante, este mosaico identitario está formado por las imágenes tomadas desde el margen de Álvaro hacia el centro de los emigrantes -son las imágenes que Álvaro había tomado con su cámara, y que había creado en su imaginación bajo la luz de las biografías. Además, el cometido del exiliado que llega a constituirse en el último capítulo como el elemento constituyente de la identidad marginada/exiliada, también es el fruto de las imágenes mencionadas, y del deseo de poner su identidad al servicio de la memoria marginada del pueblo: «deja constancia al menos de este tiempo no olvides cuanto ocurrió en él no te calles» (Goytisolo, 2005: 435). Esta corriente de conciencia de Álvaro está entrecortada con la indicación en el catalejo: «INTRODUZCA LA MONEDA», que profundiza el estar en el margen, mirando y atestiguando, sintiendo la identidad como un caleidoscopio de los Otros.

Desde el contacto con las imágenes propagandistas de un país nuevo por un lado, y con las imágenes de los desterrados de esta España por otro, resalta un rasgo característico de la identidad marginada de Álvaro, esto es, la pasión por la libertad. Habiendo sido construido desde el contraste con el país controlado por la dictadura, que tomó forma de Inquisición y plantó un espía en el alma de cada ciudadano, el lector es retraído al punto culminante posicionado ante la imagen que Álvaro trata de rescatar del olvido. Es la imagen de la bandera roja destacada contra el polo ocre que «es el grito de la antigua y amordazada libertad» (Goytisolo, 2005: 148). Amordazada como el mismo Álvaro, la 
libertad termina siendo el rasgo distintivo de su identidad exiliada, que él saluda con lágrimas en los ojos. Salvando esta seña e incorporándola en el proceso de constitución de su Yo, Álvaro se recuerda a sí mismo en la provincia de Yeste: «Orador te sentías y, borracho, les arengabas: 'Desde siempre esperáis vuestra oportunidad. [...] La muerte no importa. Unos instantes - unos breves instantes - de libertad valen - lo sabemos ahora - toda una eternidad de siglos'» (Goytisolo, 2005: 144-145). Este grito representa la esencia de la vida marginada, que no le permitió vivir de otra manera.

No obstante, el protagonista de Goytisolo sigue en la posición del marginado, intensificada al regresar a su patria con el fin de rodar el documental en el año 1958, en vísperas al encierro en las torres en Yeste. Desde el primer encuentro la gente tomaba a Álvaro y a sus compañeros por extranjeros, y miraban su cámara de dieciséis milímetros con recelo y hostilidad, es decir, les tomaba por los Otros. Esta transformación de Álvaro en el Otro de su propia patria parece ser una técnica narrativa más de Goytisolo para cumplir con la obligación de objetividad cinematográfica de su protagonista. De acuerdo con el papel del Otro en la «España nueva», Álvaro tampoco reconoce su ciudad natal a finales del último capítulo, donde se crea una atmósfera de la Otredad dialéctica: el país nuevo es el Otro del país que Álvaro conocía y al que aspiraba, y simultáneamente él mismo fue el Otro de una sociedad creada bajo la bandera franquista, ante un mundo con fachada de industrialización y progreso. Es así como la Otredad y lo Otro acaban apropiándose de las formas y modos de ser de Álvaro, y este contacto libera a Álvaro de los conceptos inculcados desde la infancia. Por la Otredad identificadora del protagonista podemos tomar también al Poder y a los representantes del discurso gobernante que influyeron la identidad marginada de Álvaro Mendiola, lo que el mismo autor escribiendo sobre su propia existencia, ha notado (en relación con la muerte del General Franco):

Muchas veces [...] he pensado en este personaje cuya sombra ha pesado sobre mi destino con mucha mayor fuerza y poder que mi propio padre. Lo que hoy soy, a él lo debo. El me convirtió en un Judío Errante, en una especie de Juan sin Tierra, incapaz de aclimatarse y sentirse en casa en ninguna parte. (Goytisolo 1991: 116)

De estas palabras podemos concluir que el mismo autor se había lanzado a la búsqueda de su propia identidad, creando su Yo narrativo, regalado a Álvaro Mendiola, su propio alter ego. Así la fuerza del Alter, esto es, del Otro, demuestra la función constituyente también para la identidad del autor. 


\section{La constitución vía amor}

En la novela Señas de identidad Goytisolo consigue crear un modo específico de constitución a través de las personas que entraron en la imagen de la vida marginada -es la constitución a través de la persona amada. Estas imágenes reviven a través de las hojas de atlas, cuyas fronteras internacionales han compuesto las señas de una historia común que Álvaro compartía con su amada Dolores. Reviviéndola, Álvaro se coloca en la posición descrita por Levinas, que subraya que únicamente a través del Otro nos conoceremos a nosotros mismos (Levinas, Peperzak, 2005: 22). Esta es la razón que incita a Álvaro a encontrarse a sí mismo en la historia de su amor, sentado junto a Dolores en su casa familiar.

Sería importante destacar que Dolores se encontraba en la misma posición que Álvaro, pues había dejado a su familia y a España, y como resultado se encontraba ante una vida marginada y sin refugio. La situación en que ambos se encontraban en el mundo narrativo del París de los emigrantes, llevó a Álvaro a seguir su Otredad femenina, y a ayudarle como si estuviera ayudándose a sí mismo. Parece que de este modo Goytisolo logra crear un paralelismo vital, creando una sola vida repartida en dos partes: una masculina, de Álvaro, y otra femenina, de Dolores. Siguiendo las líneas de su unión, notamos que la comprensión mutua y el paralelismo de sus identidades es el lazo primordial de su amor, dejando lo físico desvalorizado y el pasado aniquilado: «La unión de vuestras lagrimas había precedido en unos días a la de vuestros cuerpos y las nupcias salobres y tiernas [...] anularon de modo imperativo vuestro pasado» (Goytisolo, 2005: 337). A continuación, el paralelismo entre las identidades enamoradas crece en gradación, corporeizándose -Álvaro observa el cuerpo de Dolores como modelado a su medida, convirtiéndolo en «tangible proyección» (Goytisolo, 2005: 338) de su espíritu. El punto culminante de su unión está al alcance de la identidad primordial, sin ningún golpe histórico-social: «la luz del crepúsculo esfuminaba las líneas y contornos de los cuerpos reflejados en el espejo y os devolvía poco a poco, a ti y a ella, a vuestra remota, extraviada identidad» (Goytisolo, 2005: 339). Llevados a sus raíces, empezaron a constituirse de nuevo y renacer de esa identidad herida y marginada: «'No hay antes contigo. Nací contigo. Empiezo a partir de ti.' [...] 'Dos años de paz y de olvido. Nací hace solamente dos años.' / 'El tiempo no existe. ' / 'Mi pasado eres tú. Mis señas de identidad son falsas.'» (Goytisolo, 2005: 348).

La historia de amor de Álvaro y Dolores y de su mutua constitución se ven trasladadas a un narrativo diferente -al de la miseria, desgracia y negación de 
la identidad. El proceso opuesto de amor comienza con Dolores en Ginebra, donde un tío de Álvaro, Néstor, se había colgado. La atmósfera de aniquilación progresa paulatinamente con el acercamiento del momento de aborto y de la destrucción del «germen de la odiada semilla» (Goytisolo, 2005: 364). Las imágenes de la continuación perdida de sus identidades giran en torno a una identidad liberada de ataduras, que por lo tanto está destinada a la muerte: el motivo obsesivo en los pensamientos de Álvaro, despertado por la memoria del tío que se suicidó. Después de Ginebra, el punto más agónico y determinante para la constitución de la identidad marginada a través del amor, lo notamos en el distanciamiento de Dolores, que está yuxtapuesto al distanciamiento de España y del mundo, descrito de este modo: «El paisaje se transformó. [...] La nada se abrió a tus pies. [...] El mundo extraño a ti y tú extraño al mundo. Roto el contacto entre los dos. Irremediablemente solo» (Goytisolo, 2005: 369). La oposición entre las nupcias salobres y tiernas del comienzo y una imagen alegórica de una sandía partida en dos en Ginebra, es la oposición paralela a la constitución y aniquilación de la identidad a través de amor.

La necesidad de aniquilarse y escaparse de la identidad indefinida y huidiza se puede observar como una necesidad de renacer y constituirse. Es el impulso interno que había llevado a Álvaro al tobogán gigante de la feria en la Place de la Bastille, después del cual sufrió una caída en el boulevard Richard Renoir por un ataque de corazón. Unos meses antes de su regreso a España, Álvaro está en la entrada a su nueva identidad, en el hospital de Santa Antoine en el París de los exiliados, donde se ve completamente desarraigado y desnudo en un margen espacioso de su libertad: «nacido a sus treinta y dos años sin señas de identidad» (Goytisolo, 2005: 380). Al salir del mundo ambivalente y contrapuntual, en que vagaba en el límite entre la vida y la muerte, Álvaro consiguió la identidad cero, que le empujó a buscar las señas para constituir su ipseidad y mismidad. Aniquilada de este modo, la identidad volvió al punto de partida en su círculo narrativo -es la resurrección, anastasis-, en términos de James Miller: el renacimiento después de despertarse (Cornejo-Parriego, 1998:183).

\section{Conclusión}

Llevando a su protagonista del punto de partida al punto final de la búsqueda, parece que Goytisolo ha dilatado el final, puesto que el punto final de la constitución de la identidad marginada no ha sido establecido. Así el punto final es un nuevo punto de partida después del renacimiento de Álvaro en el hospital, y el círculo sigue desarrollándose, formando así un camino espiral. 
¿Podríamos entonces decir que la identidad marginada llega a constituirse? Este análisis terminará con esta pregunta, olvidando el trabajo analítico de disección, y dejando a la novela-objeto su vida propia. La razón puede encontrarse en la novela misma, puesto que el margen, como la identidad de Álvaro Mendiola, nunca puede cerrarse ni terminarse: está en un continuum, huidiza y constituyente, existiendo únicamente en tránsitos, sin llegar a obtener un significado unificador. Este significado unificador lo encontramos paradójico - diseminado entre las imágenes, biografías e historias de los Otros y sus identidades correspondientes, como es también el de Álvaro Mendiola para su autor Juan Goytisolo, al que él mismo recurrió en su búsqueda personal. De esta manera el diálogo en el proceso de constitución de lo marginado es permanente, y la identidad marginada llega a definirse solo a través de una relación recíproca y dialéctica. No obstante, la posibilidad de constitución de identidad marginada se aniquilará paulatinamente en las novelas que siguen con la Trilogía de Álvaro Mendiola, para las cuales Señas de identidad sirvió como una novela preliminar en este gran tríptico sobre el desarraigo.

\section{Bibliografía}

Abradelo Usera, I. (2005): «Escrito en primera persona». En: María Dolores de Asís Garrote (ed.), La novela contemporánea española. Madrid: Instituto de Humanidades Ángel Ayala y Fundación Universitaria San Pablo, 51-61. Anderson, R. (1974): «Señas de identidad: Chronicle of a Rebellion». En Journal of Spanish Studies: Twentieth century, Vol. 2, No. 1, (Spring), 3-19.

Barrero Pérez, O. y Cercas, J. (1999): «La novela». En: Rico, F.: Historia y crítica de la literatura española: Época contemporánea: 1939-1975, Vol. 8/1, Barcelona: Crítica, 352-359.

Cornejo-Parriego, R. (1998): «Del discurso de la enfermedad al discurso de la identidad en Juan Goytisolo». En: Arizona Journal of Hispanic Cultural Studies, Vol. 2: http://www.jstore.org/stable/20641422 (11/06/2012).

De Asís Garrote, M. D. (2005): «Novela española contemporánea. Tendencias literarias de la postmodernidad». En: María Dolores de Asís Garrote (ed.), La novela contemporánea española, Madrid: Instituto de Humanidades Ángel Ayala y Fundación Universitaria San Pablo, 33-51.

Edward W., S. (2000): Reflections on exile and other essays. Cambridge: Harvard University Press.

Goytisolo, J. (1977): Disidencias. Barcelona: Seix Barral. 
Goytisolo, J. (1991): «Cronología». En: Semana de autor sobre Juan Goytisolo, ed. Manuel Ruiz Lagos. Madrid: Ediciones de Cultura Hispánica, 103-122.

Goytisolo, J. (2005): Señas de identidad. Madrid: Alianza Editorial.

Levinas, E., Peperzak A. T. (2005): To the Other: Introduction to the Philosopby of Levinas, Indiana: Purdue University Press.

Osborne, J., Wintle, M. (2006): «The construction and allocation of identity through images and imagery: an introduction». En: Studia Imagologica: Image into Identity, Constructing and Assigning Identity in a Culture of Modernity, Vol. 11. Amsterdam: Editions Rodopi, 15-30.

Pope D., R. et al (1999): «Hacia los años cincuenta». En: Historia y crítica de la literatura española: Época contemporánea: 1939-1975, Vol. 8/1. Barcelona: Crítica, $450-459$.

Riker, P. (2004): Sopstvo kao drugi. Beograd: Jasen (traducido por Spasoje Ćuzulan).

Rodríguez Cacho, L. (2009): Manual de Historia de la Literatura española, Siglos XVIII al XX (basta 1975), Vol. 2. Madrid: Castalia.

Sánchez Vidal, A. (1980): «Renovación de la novela española en los años sesenta». En: Cuadernos de investigación filológica, No. 6: http://www. dialnet.unirioja.es/descarga/articulo/68909.pdf (10/06/2012).

Sanz Villanueva, S., (1977): Lectura de Goytisolo. Barcelona: Víctor Pozanco.

Sanz Villanueva S., Sobejano, G. (1999): «Los años sesenta: de la renovación a la experimentación». En: Historia y crítica de la literatura española: Época contemporánea: 1939-1975, Vol. 8/1. Barcelona: Crítica, 526-534.

Sanz Villanueva, S., Sobejano, G. (2012): «Prólogo». En: Juan Goytisolo, Trilogía de Álvaro Mendiola. Barcelona: RBA Libros, 11-33.

Soldevila Durante, I. (2001): Historia de la novela española (1936-2000), Vol. 1. Madrid: Cátedra.

Ugarte, M. y otros (1999): «Juan Goytisolo». En: Historia y crítica de la literatura española: Época contemporánea: 1939-1975, Vol. 8/1. Barcelona: Crítica, 481489 .

Zambrano, M (1995): Las palabras del regreso, edición y presentación Mercedes Gómez Blesa, Salamanca: Amaru. 


\section{Jelica Veljović}

Universitiy of Kragujevac

\section{The constitution of marginalized identity in Signs of identity by Juan Goytisolo}

Keywords: postwar novel, identity, otherness, marginalization

The main objective of the article is to investigate the modes of constitution of a marginalized and exiled identity in the novel Signs of identity by Juan Goytisolo. It is categorised as a "testimony and postwar novel", and the subjects' constant search of themselves, of their Self and all the elements that constitute their identity is central to the work. The novel is set in the postwar socio-historical period and the protagonist - Alvaro Mendiola - searches for his identity in his childhood memories and family pictures, but also amongst all the Others whose life stories intertwine with his journey of identification. Tracing his line of identity formation, we found three different routes: the first through the genealogical records, the second through the concept of Otherness and the last one through love. We find Identity as a kaleidoscope containing all the Others who served as moulds for his Identity, yet leaving it undefined and incomplete. Therefore, the identity of an exiled and marginalized individual is always in flux, continually reinitiating the constitution of the Self that had been eradicated from its first and formative imagery: the family and the fatherland. 


\section{Jelica Veljović}

Univerza v Kragujevcu

\section{Vzpostavitev marginalizirane identitete v Señas de identidad Juana Goytisola}

Ključne besede: povojni roman, identiteta, drugost, marginalizacija

Namen prispevka je raziskati načine, kako se v romanu Señas de identidad Juana Goytisola vzpostavi marginalizirana in pregnana identiteta. Roman, ki je označen za roman pričevanja in povojni roman, je bistveno delo za razumevanje subjektov, ki nenehno iščejo sebe, svoj jaz, in elemente, ki konstituirajo njihovo identiteto. Ker je identiteta protagonista romana Álvara Mendiola razpršena $\mathrm{v}$ španskem povojnem družbenozgodovinskem kontekstu, jo skuša vzpostaviti s pomočjo spominov iz otroštva, družinskih podob, vendar tudi s pomočjo različnih drugih, katerih zgodbe prekrižajo njegovo pot identifikacije. Če sledimo tej poti oblikovanja protagonistove identitete, lahko določimo tri različne poti: prva s pomočjo genealoških podob, druga poteka prek koncepta drugosti in tretja s pomočjo ljubezni. Tako identiteto vidimo kot kalejdoskop, sestavljen iz vseh drugih, ki so ji služili kot model, in je zato nikoli ni mogoče opredeliti in izpopolniti. Tako je identiteta izseljenca/ pregnanca - obrobneža - vedno v gibanju, vedno znova se vrača na začetek konstituiranja, ker je ločena od prvotnih podob, ki so oblikovale njen jaz: od svoje družine in domovine. 